\title{
RELATIONSHIPS BETWEEN MODELS OF FAMILY EDUCATION AND DEVIANT BEHAVIORS AMONG TEENAGERS
}

\author{
Thu Huong Tran ${ }^{1}$, Thu Huong Tran ${ }^{1}$, Thi Ngoc Lan Le², Thi Minh Nguyen ${ }^{3}$, \\ \& Thu Trang Le ${ }^{4}$ \\ ${ }^{l}$ Department of Social Psychology, Faculty of Psychology, VNU-University of Social Sciences \\ and Humanities in Hanoi/Affiliation (Vietnam) \\ ${ }^{2}$ Postgraduate, Faculty of Psychology, VNU-University of Social Sciences and Humanities \\ in Hanoi/Affiliation (Vietnam) \\ ${ }^{3}$ Vietnam Court Academy, The Supreme People Court, Hanoi/ Affiliation (Vietnam) \\ ${ }^{4}$ People's Police Academy, Hanoi/ Affiliation (Vietnam)
}

\begin{abstract}
Background: An important predictor of adolescents' developmental outcomes is a model of family education, described in terms of parental behaviors. Various parental behaviors were strongly associated with increasing risk of deviant behaviors at school. Methods: The study was conducted on 566 adolescents, comprising 280 males $(49.5 \%)$ and 286 females $(50.5 \%)$, of grade $11^{\text {th }}$ and $12^{\text {th }}$, of age rang 16-17 years from different government colleges in Vietnam. There were 2 self-reported scales to be used: Parental behavior scale; Adolescent deviant behaviors; Data was analyzed by using reliability analysis to examine the psychometric properties of the scales. Results: There was a strong, negative correlation between school deviant behaviors in adolescents and the parental support model (with $r_{\text {father }}=-.53, r_{\text {mother }}$ $=-.61, p$-value $<.01$ ); a strong, positive correlation between the school deviant behaviors and the parental psychological control model (with $r_{\text {mother }}=.45$ and $r_{\text {father }}=.47, p$-value $<.01$ ). Conclusions: In family education, positive behaviors used by parents such as supportive, warmth and moderate control would have a positive impact on the adolescent's behavioral development; conversely, parents' psychological control would negatively affect and give rise to deviant behaviors among adolescents.
\end{abstract}

Keywords: Family educational model, parenting behavior, deviant behavior, adolescents, relationships.

\section{Introduction}

Over the past 10 years, incidences of deviant behaviors among adolescents in Vietnam have become more serious. Recent studies on deviant behaviors have mostly referred to noticeable slices, such as school violence, sexual violence, spreading bad news on the internet, acts in violation of laws, abortion, unsafe sex (SAVY 2, 2010), cheating, being rude to teachers, using drugs, bullying schools ... (Hoang Gia Trang, 2003/2015); of which, acts of bullying, insulting, threatening others in public places have become more striking. It seems that the family, school and society are gradually losing control over adolescents with deviant behaviors and the use of educational authority to deal with these problems has not had expected outcomes.

The World Health Organization defines adolescence as the period between child and adult age, from 10 to 19 years. Despite the differences in the concepts of adolescence, all studies in the world and in Vietnam confirm that this is a period of storm and stress with strong changes in all aspects: biological, cognitive, emotional, behavioral and, interpersonal relationships (Truong Thi Khanh Ha, 2013). This age is influenced by diversified environmental-related effects (especially from family-attached relationships, interpersonal relationships outside the family) and thus, the frequency of deviant behaviors, risky behaviors in adolescents also becomes more numerous than other age groups (Eisenberg, Damon \& Lerner, 2006).

Deviant behaviors are considered socially unacceptable behaviors (Cheng, 2012), an unusual, abnormal, unexpected behavior, attitude, opinion or different from the behaviors, attitudes and opinions of the majority; these may be antisocial behaviors (Eisenberg, Damon \& Lerner, 2006; Giacolone \& Greenberg, 1997), or dysfunctional, inadequate behaviors (Vardi \& Weitz, 2004; Mushtaq \& Kausar, 2018). It is important to consider factors for decreasing (protective factors) or increasing (risk factors) these behaviors. The protective factors are related to individual characteristics of the student and the family environment, school environment. Protective factors may be a social support from people who are 
important, meaningful and positive to young people (Bearn et al., 2002; Burton \& Marshall, 2005), a feeling of belonging an environment (Coker \& Borders, 2001). An important predictor of adolescents' developmental outcomes is a model of family education, described in terms of parental behaviors. Various parental behaviors were strongly associated with increasing risks of deviant behaviors at school (Barrera \& Li, 1996; Rutter, Giller \& Hagel, 1998; Brook \& al., 1997). Numerous studies have shown that family education had a significant influence on adolescent deviant behaviors (Cheng, 2001), such as parental supervision and control (Laser, Luster \& Oshio, 2007). Weak parental involvement and low parental control are related to deviant behaviors in children (Sampson \& Laub, 1994: 523).

In Vietnamese culture, parenting is greatly influenced by three traditional religions (including Buddhism, Confucianism and Taoism), ancestor cult and collective values (Coulet, 1933, cited by Tran Thu Huong, 2007; Luong Can Liem, 1992/2005). The attachment among family members is also a protective factor against deviant behaviors. In contrast, the majority of adolescents who have ever engaged in risky behavior refer to causes such as family conflict and lack of harmony with parents.

Therefore, this study aims to find and clarify the relationship between family education models (modeled by parental behaviors) and deviant behaviors among Vietnamese teenagers (focusing on high school students). At the same time, some independent variables such as age, gender, academic achievement, parental educational level and occupation, were included in the analysis to examine their influence on the above relationship and to find a predictive model for deviant behaviors.

\section{Methods}

This research was conducted on 566 students in Vietnamese high schools, including 280 males $(49.5 \%)$ and 286 females $(50.5 \%)$, of grade $11^{\text {th }}(\mathrm{n}=405)$ and $12^{\text {th }}(\mathrm{n}=161)$, of age rang $16-17$ years, from October 2019 to September 2020. The majority of participants $(88.3 \%)$ were intact families. The level of students' academic achievement varied, around $7.2 \%$ of them had a good level $(n=41)$, $10.4 \%$ were at weak and average level $(\mathrm{n}=59)$, and $82.3 \%$ were fairly good $(\mathrm{n}=466)$. This was a cross-sectional research. The convenience sampling was performed.

Parental Behaviors Scale (Family Education) were measured using a 23-item scale proposed by Brian, Barber, Stolz, Olsen, Collins and Burchinal (2005), and 2 items built by research team. This 25-item scale was a child-report measure which comprised of three subscales: Parental Support, Parental Psychological Control and Behavioral Control. The alpha's Cronbach coefficient of the whole scale for the father is: .71 and for the mother is .65. Parental support was measured using the 10-item subscale from the revised Child Report of Parent Behavior Inventory (Schaefer, 1965; Schuldermann \& Schuldermann, 1988). The alpha's Cronbach coefficient of this sub-scale for fathers is: .85 and for mothers is .73. The parental psychological control subscale consisted of 8 items extracted from Psychological Control Scale-Youth Self-Report (PCS-YSR; Barber, 1996) and 2 items which were built to rely on cultural characteristics of Vietnamese students in high. The alpha's Cronbach coefficient of this sub-scale for the father is: . 77 and for the mother is .83. Parental behavioral control was measured using 5 -item scale that was opted in family research with adolescents (e.g., Brian, Barber, Stolz, Olsen, Collins and Burchinal, 2005). The alpha's Cronbach coefficient of the sub-scale in the father is: .71 and in the mother is .66 .

Adolescent-Reported Deviant Behaviors Checklist enumerated 37 problem behaviors in Vietnamese high-school students. To design a scale adapted to the sociocultural, educational and political characteristics in Vietnam, the research team has consulted, synthesized and opted for 27 items in international self-report delinquency studies (e.g., Elliot \& Agenton, 1980; Junger - Tas, Terlouw \& Klein, 1994; Ni He \& Marshall, 2012). The remaining 10 items were designed by the research team based on the behavioral cultural rules of the Ministry of Education and Training in Vietnam, in consultation with head teachers and asking students about problematic behaviors occurring at school. This scale is structured into 4 sub-scales, including: 1/The violation of learning rules and school rules (17 items, $\alpha=.91$ ); $2 /$ School conducts ( 8 items, $\alpha=.87$ ); 3/Bullying behaviors at school ( 7 items, $\alpha=.87$ ); and $4 /$ Behavior related to sexuality ( 5 items, $\alpha=.85$ ).

\section{Results of research}

\subsection{Evaluations of school deviant behaviors in adolescents}

Independent sample T- test analyses of school deviant behavior groups between two groups of boys and girls showed that the boys had higher levels of school deviant behaviors than girls in all 4 groups of school deviant behaviors (see Table 1). 
Table 1. Comparison of the average scores of school deviant behaviors in high school students.

\begin{tabular}{|l|c|c|c|c|}
\hline \multirow{2}{*}{ Groups of school deviant behaviors } & \multicolumn{3}{|c|}{ Boys } & \multicolumn{2}{|c|}{ Girls } \\
\cline { 2 - 5 } & $\boldsymbol{M}$ & $\boldsymbol{S D}$ & $\boldsymbol{M}$ & $\boldsymbol{S D}$ \\
\hline Violation of learning rules and school rules $\mathrm{t}_{(566)}=3.96, \mathrm{p}=. \mathbf{0 0 0}$ & 2.06 & 0.73 & 1.87 & 0.37 \\
\hline School conducts $\mathrm{t}_{(566)}=4.95, \mathrm{p}=. \mathbf{0 0 0}$ & 1.89 & 0.85 & 1.62 & 0.35 \\
\hline Bullying behaviors at school $\mathrm{t}_{(566)}=4.66, \mathrm{p}=. \mathbf{0 0 0}$ & 1.73 & 0.78 & 1.48 & 0.37 \\
\hline Behavior related to sexuality $\mathrm{t}_{(566)}=6.364, \mathrm{p}=. \mathbf{0 0 0}$ & 1.66 & 0.81 & 1.32 & 0.33 \\
\hline
\end{tabular}

As can be seen, the deviant behaviors in school often and firstly belonged to the behaviors related to learning; in other words, deviant behaviors frequently revolved around issues associated with a student's consciousness, attitudes, responsibilities and obligations. Comparing groups of students with different school deviant behaviors with the Independent sample T-test and the One-way ANOVA statistical methods, the research team noted that private school students had more school deviant behaviors than public school students in all four groups of deviant behaviors. Students with average academic performance had a higher level of deviant behaviors than the groups of students with good and excellent performance, especially in the two groups of deviant behaviors as regards to violations of learning rules and school conducts. The less time parents spent with their children (1 hour or less), the higher the student's level of deviant behavior, and vice versa. The time that parents spent with their children is a proof of a family's quality of life, and at the same time shows parents' concerns for their children and the feelings of members of their family. Parental marital status influenced the degree of deviant behaviors in high school students. For intact families, the level of school deviation among students was lower than for "separated" or "divorced" families. This means that, in insufficient families, children might lack the attention, care and supervision of a parent. The traumas that children had to suffer from living in an insufficient family can also cause the occurrence of their deviant behaviors.

\subsection{Parenting behavior models reported by adolescents}

Table 2. Comparison of the average scores for all dimensions of the parenting behaviors reported by students.

\begin{tabular}{|c|c|c|c|c|c|c|c|}
\hline & \multicolumn{7}{|c|}{$\mathrm{T}$-value $=2$} \\
\hline & \multirow[t]{2}{*}{$t$} & \multirow[t]{2}{*}{$d f$} & \multirow[t]{2}{*}{ Sig. (2-tailed) } & \multirow[t]{2}{*}{ Mean } & \multirow[t]{2}{*}{$M . D$} & \multicolumn{2}{|c|}{$95 \%$ C.I } \\
\hline & & & & & & - & + \\
\hline Supportive Father & -9.417 & 565 & 0.00 & 1.78 & -.21692 & -.2622 & -.1717 \\
\hline Psychological control of Father & .099 & 565 & 0.92 & 2.00 & .00199 & -.0373 & .0413 \\
\hline Behaviora control of Father & -13.787 & 565 & 0.00 & 1.66 & -.33834 & -.3865 & -.2901 \\
\hline Supportive Mother & 2.030 & 565 & 0.04 & 2.04 & .04527 & .0015 & .0891 \\
\hline Psychological control of Mother & 3.739 & 565 & 0.00 & 2.08 & .07827 & .0372 & .1194 \\
\hline Behavioral control of Mother & -13.751 & 565 & 0.00 & 1.70 & -.31625 & -.3614 & -.2711 \\
\hline
\end{tabular}

The data in Table 2 were analyzed by the One sample T-test with T-value $=2$ showing that, of three dimensions of parenting behaviors reported by high school students, the psychological control aspect was still the common behavior above all others in parents, followed by the parental support aspect (it should be noted that the students' assessment of this aspect for mothers was quite far from fathers' support), and finally was the behavioral control.

The results on the manifestation levels of parenting behaviors showed that, among three mentioned groups, the psychological control dimension was "high" (strong/tight), being the most dominant; in which, the distance between fathers (53.4\%) and mothers $(67.3 \%)$ was quite clear. Second was the dimension of strong parental support, this rate was $64.8 \%$ for mothers, while $41.7 \%$ for fathers. As many as two-third of the students on the survey rated their parents having loose behavioral control, only $32.3 \%$ for their fathers and $35.9 \%$ for their mother as having strict behavioral control.

Thus, the fact that children evaluated the mother's behavioral aspects (strong supportive behavior, at the same time, tight psychological control) higher than the father's ones clearly reflected the role and cohesion of father and mother in Vietnamese families; in which, the presence and influence of the mother dominates in the early stages of development of the child.

\subsection{Correlation between school deviant behaviors in adolescents and parenting behaviors}

The results in Table 3 pointed out: 1/There was a strong, negative correlation between school deviant behaviors in general and the parent support group with $\mathrm{r}_{\text {father }}=-.53, \mathrm{r}_{\text {mother }}=-.61 ; 2 /$ There was a strong, positive correlation between the school deviant behaviors and the psychological control group; in which, the correlation coefficients for mother and father were: $r_{\text {mother }}=.45$ and $r_{\text {father }}=.47$. This was also a significant correlation level, showing that in the family, a parent, especially the mother, strengthened 
his/her management, supervision and manipulation of his/her child psychologically, the higher the risk of the child's school deviant behavior; 3/There was an negative, weak correlation between school deviant behaviors and behavioral control group; in which, the level of negative correlation for father $\left(\mathrm{r}_{\text {father }}=-.30\right)$ was higher than for mother $\left(\mathrm{r}_{\text {mother }}=-.17\right)$.

Table 3. Correlation coefficient between school deviant behaviors in general and parenting behaviors.

\begin{tabular}{|l|c|}
\hline \multicolumn{1}{|c|}{ Dimensions of parenting behaviors $(n=566)$} & School deviant behaviors in students \\
\hline Supportive Father & $\mathbf{- . 5 3} * *$ \\
\hline Psychological control of Father & $.45^{* *}$ \\
\hline Behavioral control of Father & $-.30^{* *}$ \\
\hline Supportive Mother & $\mathbf{. 6 1 * *}$ \\
\hline Psychological control of Mother & $.47^{* *}$ \\
\hline Behavioral control of Mother & $-.17^{* *}$ \\
\hline${ }^{* *} \mathrm{p}<.01$ &
\end{tabular}

The different groups of deviant behaviors had a quite tight correlation with three dimensions of parenting behaviors. Parent support dimension had a strong, negative correlation with all 4 groups of school deviant behaviors in high school students, in which, the correlation coefficients for mothers were higher than those for fathers. Parental Psychological control dimension had a significantly positive and quite tight with all four groups of deviant behaviors at school; in which, the correlation level for fathers and for mothers was quite similar, with $p$-value $<.01$. Finally, the parental behavior of psychological control was positively and quite strongly correlated with all four groups of deviant behaviors in high school students, with the $r$ coefficient ranging from .39 to .46 . So it can be affirmed that if the father or mother uses psychological control behavior, the child's trauma is the same.

\section{Discussions and conclusions}

In Vietnamese folk, when it comes to family education, people often refer to the idiom: "A child is spoiled by his mother, a grandchild is spoiled by his grandmother". However, the power in the Vietnamese family belong to the man, because they are responsible for making money, as well as economic holders in the family (land, farmland, and property are all owned by the father and "only pass in to the son") (Nguyễn Từ Chi, 1989). Thus, whether the father has implicitly assigned the responsibility of raising and educating the children through the woman (wife, mother); on the surface, does the father seem less present or absent in relationships with the child than the mother's image?

There was a question to be asked: why did students value their mothers both strongly supporting their children and controlling them psychologically closely? From a practical point of view, parental behaviors (or parental education in the family) and school deviant behaviors in high school students were correlated. The supportive behavior was considered as the most ideal of the three types of parenting behaviors. Mothers' supportive behaviors had an effective role of controlling, eliminating and minimizing the level of deviation more than that of fathers. Besides, the parental control of the child's behaviors was inversely correlated with all four groups of deviant behaviors, in which the father's supervision had more impact on the child's behaviors than that of the mother.

There may be a question posed instead of the conclusion of this paper, which is: whether parents have a lot of support and effective control in their children's behaviors is the best educational method to produce fewer school deviant behaviors in children or not? And vice versa, a weak support (neglect) and overly high psychological control and too high or too low behavioral control of parents are the highest risk for the formation and development of school deviant behaviors in high school students or not?

\section{Acknowledgments}

This research is funded by Vietnam National University, Hanoi (VNU) under project number QG.19.38.

\section{References}

Barber, B. K. (1996). Parental psychological control: Revisiting a neglected construct. Child Development, 67(6), 3296-3319.

Barrera, M., \& Li, S. A. (1996). The relation of family support to adolescent's psychological distress and behavior problem. In G. R. Pierce, B. R Sarason \& I. G. Sarason (Eds), Handbook of social support and the family. New York: Plenum Press. 
Bean, R. A., Barber, B. K., \& Crane, D. R. (2006). Parental support, behavioral control, and psychological control among African American youth: The relationships to academic grades, delinquency, and depression. Journal of Family Issues, 27(10), 1335-1355.

Bộ Y tế (2010). Điều tra quốc gia về vị thành niên và thanh niên Việt Nam (SAVY2)

Brian, Barber, B.K., Stolz, H.E., Olsen, J.A., Collins, W.A. \& Burchinal, M. (2005). Parental Support, Psychological Control and Behavioral Control: Assessing relevance across time, culture and method. Monographs of the Society for research in child development, Serial No. 282, Vol. 70, No. 4, Published by: John Wiley \& Sons, Inc., pp. i+v+vii+1-147.

Brook, J. S., Wh, M., Balka, E. B., \& Cohen, P. (1997). Drug use and delinquency: Shared and unshared risk factors in African American and Puerto Rican adolescents. The Journal of Genetic Psychology, 158, 25-39.

Burton, J. M. \& Marshall, L.A. (2005). Protective factors for youth considered at risk of criminal behavior: Does participation in extracurricular activities help? Criminal Behavior \& Mental Health, 15(1), 46-64.

Cheng, J. (2001). Family violence victimization as an influential cause to juvenile deviance. Journal of Criminology, 8, 215-246.

Cheng, J. (2012). The effect factor for students' deviant behavior. The Journal of Human Resource and Adult Learning, Vol. 8, Num. 2, December 2012, pp 26-32.

Coker, J. K., \& Borders, L. D. (2001). An analysis of environmental and social factors affecting adolescent problem drinking. Journal of Counseling \& Development, 79, 200-208.

Elliott, D. S., Huizinga, D., \& Ageton, S. S. (1985). Explaining delinquency and drug use. USA: Sage Publications.

Giacalone, R. A., \& Greenberg, J. (Eds.). (1997). Antisocial behavior in organizations. Sage Publications, Inc.

Hoàng Gia Trang (2015), Giáo dục phòng ngừa hành vi lệch chuẩn ở HS THPT, Tạp chí Khoa học giáo $d u c$, số 120 , tháng 9 .

Junger - Tas, J., Terlouw, G.J \&Klein, M W (1994). Delinquent behavior among young people in the western world. Fisrt results of the international seft report delinquency study. Amsterdam: Kugler publications.

Laser, J. A., Luster, T., \& Oshio, T. (2007). Promotive and risk factors related to deviant behavior in Japanese youth. Criminal Justice and Behavior, 34(11), 1463-1480

Luong Cân-Liêm (1992/2005). Bouddhisme et psychiatrie, Paris: L’Harmattan.

Mushtaq, Sh. \& Kausar, R. (2018). Exploring dimensions of deviant behaviour in Adolescent boys. Journal of Behavioural Sciences, Vol. 28, No. 1

N. Eisenberg, W. Damon, \& R. M. Lerner (Eds.), Handbook of child psychology: Social, emotional, and personality development (p. 1-23). John Wiley \& Sons, Inc.

Nguyễn Từ Chi (1996). Góp phần nghiên cúu văn hóa và tộc nguời. Hà Nội: Tạp chí Văn hóa Nghệ thuật, Văn hóa thông tin.

Ni He \& Marshall, I.-H. (2012). A multi-city Assessment of Juvenile Delinquency in the U.S.: A Continuation and Expansion of the International Self-Report Delinquency Study (ISRD). 2006IJCX0045/ISRD-2 US Final Technical Report. This document is a research report submitted to the U.S. Department of Justice.

Rutter, M., Giller, H., \& Hagel, A. (1998). Antisocial behavior in young people. Cambridge: Cambridge University Press

Sampson, R. J., \& Laub, J. H. (1994). Urban poverty and the family context of delinquency: A new look at structure and process in a classic study. Child Development, 65, 523-540.

Schaefer, E. S. (1965). Children's reports of parental behavior: An inventory. Child Development, 36, 413-424.

Schuldermann, S., Schuldermann, E. (1988). Questionnaire for Children and Youth (CRPBI-30). Unpublished manuscript. University of Manitoba; Winnipeg, Canada.

Tran Thu Huong (2007). Conduites à risque des adolescents vietnamiens et intégration de la Loi paternelle: Une étude appliquée à la prostitution et à la toxicomanie. Thèse de doctorat, Toulouse 2, France.

Trương Thị Khánh Hà (2013), Giáo trình tâm lý học phát triển. NXB Đại học quốc gia Hà Nội.

Vardi, Y. \& Weitz, E. (2004). Misbehavior in organizations: Theory, Research and Management. DOI: 10.4324/9781410609052. Lawrence Erlbaum Associates, Inc. 